\title{
NUSANTARA MASK HERITAGE MALAYSIA: INFOGRAPHIC APPLICATION DEVELOPMENT OF MASKS OF MALAYSIAN INDIGENOUS TRIBES AT THE MUSEUM OF ASIAN ART MALAYSIA BASED ON AUGMENTED REALITY AS MEDIA OF TOURISM EDUCATION
}

\author{
Lisa Sidyawati ${ }^{1}$, Joni Agung Sudarmanto ${ }^{2}$, Abdul Rahman Prasetyo ${ }^{3}$, Encik Muhammad \\ Hawari Bin Berahim ${ }^{4}$ \\ ${ }^{1}$ Email: lisasidyawati@gmail.com \\ Art and Design Department, Faculty of Letters, Universitas Negeri Malang, Indonesia \\ ${ }^{2}$ Email: jonny_oks@yahoo.co.id \\ Art and Design Department, Faculty of Letters, Universitas Negeri Malang, Indonesia \\ ${ }^{3}$ Email: dapurkartun@ gmail.com \\ Art and Design Department, Faculty of Letters, Universitas Negeri Malang, Indonesia \\ ${ }^{4}$ Email: hawari@umk.edu.my \\ Creative Technology Department, Faculty of Creative Technologi and Heritage, Universiti Malaysia \\ Kelantan, Malaysia
}

\begin{abstract}
The museum is a fun learning tool for the community. The Museum of Asian Art is one of the museums in Malaysia which was founded by Malaya University. The museum has three showroom floors and represents three civilizations; India, China and Islam. Every day the museum is very crowded by tourists to find information about artifact objects. Lots of artifacts stored in this museum include textiles, musical instruments, ceramics, masks, paintings, weapons and others. The museum itself is the right place to store and preserve ancient objects so they can still be seen and used as a source of learning and cultural preservation for the nation's next generation. This research takes the artifacts that are masks because the results of observations made by researchers, information about masks at the Museum of Asian Art Malaysia is very minimal compared to other artifacts, there are only name tags but there is no deeper information about the mask. So that it still cannot be used as a learning medium to the maximum. From this problem, researchers developed Nusantara Mask Heritage Malaysia (NUSMARI MALAYSIA) products based on Augmented Reality. The research method used is the development model into 4 steps: (1). Research and Information Collecting, (2). Planning, (3). Develop Preliminary Form Of Product, (4). Final Product Revision. The result of this development is a learning media application that can help tourists of all ages to more easily learn the mask of the Orang Asli Malaysia in the museum.
\end{abstract}

Abstrak: Museum adalah alat belajar yang menyenangkan bagi masyarakat. Museum Seni Asia adalah salah satu museum di Malaysia yang didirikan oleh Universitas Malaya. Museum ini memiliki tiga lantai ruang pamer dan mewakili tiga peradaban; India, Cina, dan Islam. Setiap hari museum ini sangat ramai dikunjungi wisatawan untuk mencari informasi tentang benda-benda artefak. Banyak artefak yang disimpan di museum ini termasuk tekstil, alat musik, keramik, topeng, lukisan, senjata dan lainnya. Museum itu sendiri adalah tempat yang tepat untuk menyimpan dan melestarikan bendabenda kuno sehingga masih dapat dilihat dan digunakan sebagai sumber pembelajaran dan pelestarian budaya untuk generasi penerus bangsa. Penelitian ini mengambil artefak yang merupakan topeng karena hasil pengamatan yang dilakukan oleh peneliti, informasi tentang topeng di Museum Seni Asia Malaysia sangat minim dibandingkan dengan artefak lainnya, hanya ada label nama tetapi tidak ada informasi lebih dalam tentang topeng. Sehingga masih belum bisa digunakan sebagai media pembelajaran secara maksimal. Dari masalah ini, para peneliti mengembangkan produk-produk Nusantara Mask Heritage Malaysia (NUSMARI MALAYSIA) berdasarkan Augmented Reality. Metode penelitian yang digunakan adalah model pengembangan ke dalam 4 langkah: (1). Pengumpulan Informasi dan Penelitian, (2). Perencanaan, (3). Mengembangkan Bentuk Awal Produk, (4). Revisi Produk Akhir. Hasil pengembangan ini adalah aplikasi media pembelajaran yang dapat 
membantu wisatawan dari segala usia untuk lebih mudah mempelajari topeng Orang Asli Malaysia di museum.

Keywords: application, infographic, mask, indigenous tribe, museum of asian art.

\section{PRELIMINARY}

Today, learning is not only done in the boundaries of classrooms, but it can be anytime and anywhere .One mean of learning that is currently popular among the younger generation is by visiting museums. Museum can be used as a funway of learning way it is outside the school walls and it presents collection objects and beautiful dioramas that can be taken into photographs and even published on social media.

In Malaysia, there are many state and private museums that can be visited every day, and they are very crowded on weekends. The visitors are both domestic and international tourists. In fact, school students and students from various universities hold lessons and find information for college assignments by coming to a museum. The Museum of Asian Art is one of the museums in Malaysia which was founded by Universitas Malaya. This museum was originally a library that housed various artifacts. In June 1980, the museum building was built close to the Faculty of Business and Accounting, the museum has three stories of showrooms that represent three civilizations; India, China, and Islam (Malay culture). Every day, the museum is very crowded with visitors who want to find information about artifacts. Lots of artifacts are stored in this museum including textiles, musical instruments, ceramics, masks, paintings, weapons, etc.

Museum itself is an appropriate place to store and preserve ancient objects so they can still be observed and used as a source of learning. It is also a mean of cultural preservation for the nation's next generation. With the existence of this museum, the young generation should be able to learn and understand the history and culture of their nation, especially related to masks. The younger generation can understand the shape, function and meaning of masks, which can further arouse a sense of wanting to preserve and a sense of belonging to one's own culture.

This study took one form of the museum's artifacts to be used as the research object, namely mask. The results of observations made by researchers at the museum shows that information about masks at The Museum of Asian Art Malaysia is very little compared to other artifacts, there are only name tags but no further information is provided about the masks. That is why mask is chosen among other artifacts. It is unfortunate because the masks that are kept in the museum are masks of primitive indigenous Malaysian tribes and there are daily stories of indigenous people that can be used as character education in those masks.

Previous studies relevant to this study are: Budi Arifitama's research entitled Cultural Heritage Digitalization on Traditional Sundanese Music Instrument using Augmented Reality with Multiple Marker Method, which was published in the Jurnal Teknologi dan Sistem Komputer in 2017. The equation with this research is to jointly develop learning media by utilizing Augmented Reality technology to introduce a cultural product. The difference with this research is, the object of research taken is in the field of music. Contributions to the research that researchers do is to provide a foundation or inspiration in choosing the form of instructional media products.

Research conducted by Andreas Jimmy Salim, entitled Perancangan Buku Kesenian Topeng Malangan di Kota Malang, was published in the Jurnal Desain Komunikasi Visual Adiwarna in 
2017. The equation with this research is equally making learning media products with traditional mask objects. The difference of this research is that the mask used as the object is the Malangan mask while the researcher belongs to the Malaysian Orang Asli mask. Contributions to the research that researchers do is a method of taking data to get the character specifications on the mask.

From inspiration to the above research and to the problem at hand. Researchers feel the need to develop an infographic that is interesting, interactive and utilizes technology, because almost all visitors at the Museum of Asian Art have gadgets that are practical and can be carried anywhere and can be used to search for information. Researchers developed NUSANTARA MASK HERITAGE MALAYSIA: Augmented Reality Masked Malaysian Infographics Application as an Education Media for Tourists who visit and want to get information about the mask.

Researchers feel the need to develop an infographic application that is attractive and interactive, and also utilizes technology, because almost all visitors in the museum have gadgets that are practical and can be carried anywhere and can be used to find information. Seeing this problem, researchers developed the NUSANTARA MASK HERITAGE MALAYSIA product: Infographic Application of Indigenous Malaysian Tribes Mask Based on Augmented Reality as Education Media for visitors who want to get information about the masks.

\section{METHOD}

Development method of the application of NUSANTARA MASK HERITAGE MALAYSIA: Infographic Application of Indigenous Malaysian Tribes Mask Based on Augmented Reality follows the development method of Borg $\&$ Gall. The reason for choosing the Borg and Gall development model is because the stages in this study are in accordance with the initial concept of development that the researcher did. Nana Syaodih Sukmadinata (2006: 169-170) explained that Borg and Gall development model contained 10 stages in implementing a research and development strategy. Considering the limitation of time, in this study, those steps are simplified into 4, as follows:

\section{Research and Information \\ Collecting}

At this stage, the researcher made observations in the field, at the Museum of Asian Arts Malaysia, to collect data to identify problems that exist in the museum as a basis for selecting solutions to problems faced by visitors. In addition, researchers also collected data about the masks of indigenous Malaysian tribes as an infographic that will be displayed on the NUSANTARA MASK HERITAGE MALAYSIA application based on augmented reality.

\section{Planning}

At this stage, the researcher compiles work steps and alternative solutions if there are problems in the preparation of the application to find a solution to the problems that occur.

\section{Develop Preliminary Form of Product}

At this stage the activities carried out are:

- Creating the application design of NUSANTARA MASK HERITAGE MALAYSIA

- Developing NUSANTARA MASK HERITAGE MALAYSIA

Application, at this stage the application has been processed into an Augmented Reality-based product

- Arrange a set of validation instruments that will be filled by expert validators

- Conducting validation with media expert validators, namely visual communication designer, grammar expert validator, and material content validator 


\section{Final Product Revision}

At this stage, the final input by the validators are used to create a finished and ready to use product.

\section{RESULTS AND DISCUSSION}

The Museum of Asian Art has been established for almost 50 years. The first recorded museum artifact is the bronze Buddha head from the Chiengsen period (1400-1550 AD), Thailand, which was given to the museum by Kun Krassri Nimanamhasminda in 1954. This contribution marked the beginning of The Museum of Asian Art which at that time was located at one of the universities in Singapore. The Museum of Asian Art was later established at the Universitas Malaya, Kuala Lumpur in 1962 in a library.

Gradually, the artifacts add up and The Museum of Asian Art had its own building in June 1980. This new building was built in the area of the Faculty of Business and Accounting. In its threestories showrooms, the museum represents three civilizations; India, China and Islam (Malay culture).

The Museum of Asian Art is home to many pieces of rare artifacts such as the Sawankhalok pottery products, a pottery product from Thailand during the 14th to 15th centuries AD. Valuable collection of stone carvings, copper items, weaponry, textiles, Malay masks are used as educational media for students and Malaysians to introduce heritage objects.

The Museum of Asian Art is located in Universitas Malaya because this museum is education oriented. The museum aims to promote Asian art to multicultural Malaysians. The museum has nearly 7,000 treasures, representing cultures from all of Asia, and covers 4,000 years of Asian history.

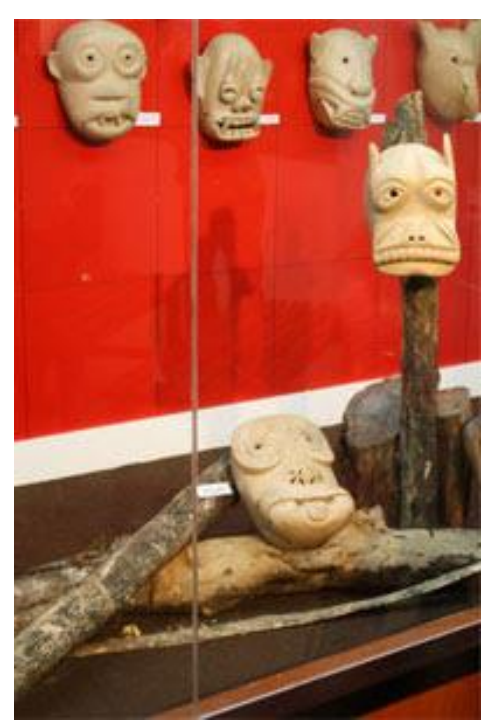

Figure 1. The Mask of the Orang Asli at the Museum of Asian Art

(Source: https: //museum.um.edu.my/ accessed in November 2019)

From the product development of the Nusantara Mask Heritage Malaysia Application and based on the previous method, it can be concluded that: two things are required to run this application, first is a marker and second is a tool to detect markers or also called an application. Augmented reality (AR) is an imaging of two-dimensional or threedimensional virtual objects projected into the real world. In other words, there is a virtual object insertion in a real world that can be seen from a screen with the input of a camera recording. The observer will feel as if they are seeing the $2 \mathrm{D}$ or $3 \mathrm{D}$ objects on the screen with a marker as a reference point for the camera's focus (Prabowo: 2015).

Nusantara Mask Heritage Malaysia application is an Augmented Reality application that is markerless. Markerless is a method that does not use markers to display a $2 \mathrm{D}$ or $3 \mathrm{D}$ object on the cell phone and gadget display. However, a markerless application still uses markers as target images that function as triggers to show $2 \mathrm{D}$ or $3 \mathrm{D}$ objects. One method of markerless application is to use Image Target, where an image is used as an object for tracking. So users can use any 
image they want. Siswanti, 2016 stated that how Image Target works in AR is that the system will detect and track features in the image that represent the recognized image by comparing features in the image with those in the database. When this feature is recognized, the image will be tracked as long as the image is within the visibility range of the camera.

The icon of this application on the cellphone and tablet screens is in the form of a plain yellow mask image with the words Nusmari Malaysia. The visualization was chosen because the masks belonging to indigenous Malaysian tribes are primitive masks and do not use ornaments like masks in Asian countries in general. The name Nusmari Malaysia under the mask image in the icon is an abbreviation of Nusantara Mask Heritage Malaysia, the abbreviation written was chosen because for the display of cellphones or tablets, the application name should be short, easy to read and does not require a lot of space. The icon is manifested to represent the real situation because the icon is something that performs a function as a marker similar to the shape of the object (Ulinnuha: 2018). The appearance of this icon can be visualized as below.

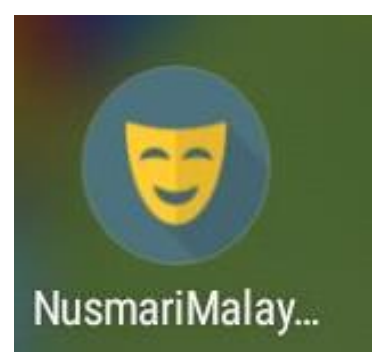

Figure 2. Nusantara Mask Heritage Malaysia Application Icon (Nusmari Malaysia) (Source: 2019 Research Results)

Marker visualization and character visualization along with infographic of indigenous Malaysian masks can be described as follows:

\section{Moyang Tok Naning}

The original story of Moyang Tok Naning in Joanne Heng's writing in the 2000 book The Mah Meri Mask Collection published by Akademi Pengajian Melayu, Universiti Pengajian Malaya states: This mask represents a handsome young man. Moyang Tok Naning had an interesting hobby which is collecting beautiful woods. After collecting woods, he often made handicrafts such as bucket wells. Beside that, he owned a lot of houses. With his good looks, he always captivated women. He was also a character who is liked because he had a cheerful face. He was also had the character of a vibrant young man.

From the story above, the researcher took the essemc of the story and display them on the visualization of augmented reality infographic, taking the essence of the story is intended to convey dense, clear and fast information for the visitors. Based on the analysis of researchers, visitors in the museum tend to read short information of the artifacts, not like reading a long narrative book. It happens because of the time factor. Many other artifact objects need to be seen, and the space factor, where many visitors also want to read the same information.

Infographics is an abbreviation of Information Graphics. Infographics are visualizations of data, ideas, information or knowledge through charts, graphics, schedules and other forms so that data, ideas, information or knowledge can be presented more than just via text and have a strong and more attractive visual impact (Kurniasih: 2015). Thus it will arouse the readers' will to understand data, ideas, information or knowledge more quickly and accurately.

The purposes of making infographics according to Kurniasih (2015) are:

1. To turn complex messages into simpler messages.

2. To present information shorter and easier to understand.

3. To explain data more easily. 
4. To monitor every change parameter periodically

Infographic visualization of Moyang Tok Naning mask is taken from the original form of Moyang Tok Naning mask combined with the indigenous Malaysian mask dance costumes.

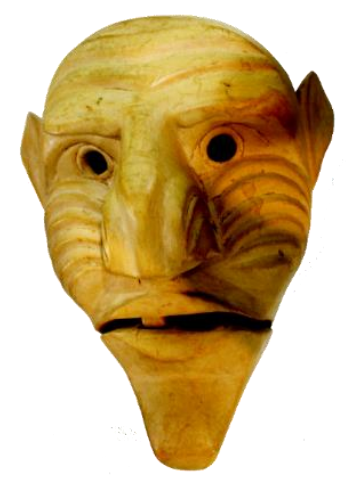

Figure 3. Moyang Tok Naning's Mask (Source: Researcher Documentation: 2019)

The mask of Moyang Tok Naning is a mask in the Museum of Asian Art, the mask is used by researchers as a markerless marker, so that visitors can directly scan the original mask of Moyang Tok Naning in the museum and then read the information that will appear on ther gadget screens.
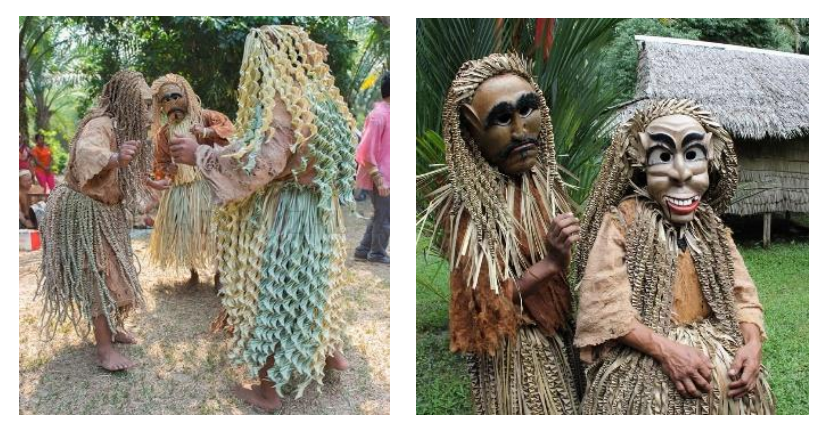

Figure 4. Panorama Magazine.com (Source: Accessed in November: 2019)

The picture above is a mask dance that is often staged by indigenous tribes of Malaysia. Costume of this dance is made from plants that grow nearby, these plants are shaped like hair and clothing.

This mask dance is a story of the social life of an indigenous Malaysian tribe, this dance is also used as a ritual for healing and casting out evil spirits. Its usage is in accordance with the character being played. The characters resemble humans, birds, animals that are on the ground and animals that swim in the water; and each character represents good, bad and witty nature (Ratos: 2003).

The purpose of making this Nusmari Malaysia application is to provide clear and accurate information for the museum visitors about the masks of the indigenous Malaysian tribes and how the mask is used in real life. After the marker is scanned on cellphone and gadget screens, they will display Moyang Tok Naning mask wearing the clothes used on the original dance performance.

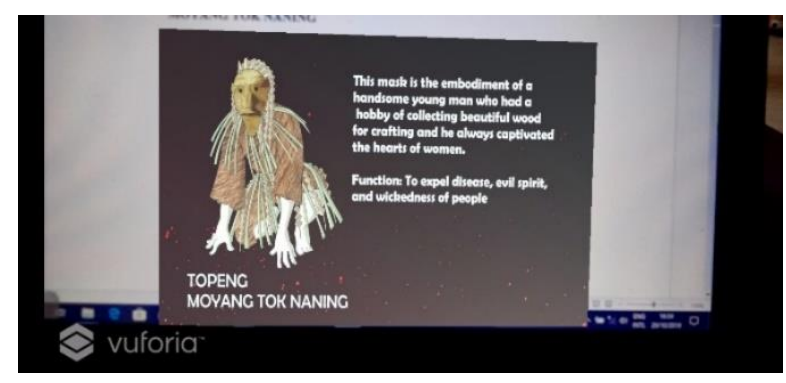

Figure 5. Visualization of Tok Naning's Mask Mask Infographics on Augmented Reality Views (Source: Research Results: 2019)

In the cellphone and gadget screens, you will see the mask of Tok Naning on the left and the information writings on the right, it was developed based on the graphic design principle, namely Sequence. Sequence is making priority sections and sorting information from what must be read first to last (ilmunesia.com:2019).

The background on the screen is made in reddish brown to represent that Moyang Tok Naning is a warm person. Reddish brown color in color theory symbolizes wholeness, stability, simplicity, friendship, and relaibility (Wicaksono: 2013). In addition, there are yellow star effects in the background that represents wealth, gold, light, life, sun, luck, joy, happiness, earth, optimism, intelligence (Wicaksono: 2013). It refers to Moyang Tok Naning who was a handsome young 
man, with a cheerful face and an energetic youth character.

\section{Moyang Kembar}

The original story of Moyang Kembar in Joanne Heng's writing in the 2000 book The Mah Meri Mask Collection published by Akademi Pengajian Melayu, Universiti Pengajian Malaya states: Once there was a couple and the wife was pregnant and later twins were born to her. The children grew up and the parents reminded them that the thin one was to be the elder brother and the fat on to be the younger brother. The parents advised them not to quarrel while they are out in the jungle and they would return.

The children in the house started abusing one another. One refused to be a younger brother and a fight started. In the end, the elder brother won the fight. The younger brother insists that he should be an elder brother so he bound up his body and fasted to become thin, but for years he could not become thin. That is why today human beings are different from one another, even if they are from the same race.

Infographic visualization of Moyang Kembar mask is taken from the original form of Moyang Kembar mask combined with the indigenous Malaysian mask dance costumes.

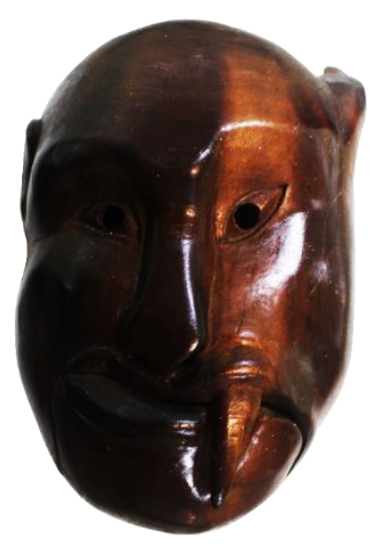

Figure 6. Moyang Kembar Mask

(Source: Researcher Documentation: 2019) 
Then the elder brother returned home and told his mother that his younger brother had been trapped by the Spirit Gayak. The parents then gathered thorny brinjals and sparrow's brinjals and hit them to the ground seven times, then chanted "If changed to human being, be a human being, but if turned into a Spirit Gayak, so be it". But it did not turn into a human being again, instead it became the shadow of the Spirit Gayak.

The infographic visualization of Moyang Gayak mask was taken from the original form of Moyang Gayak mask and combined with the Indigenous Malaysian mask dance costumes.

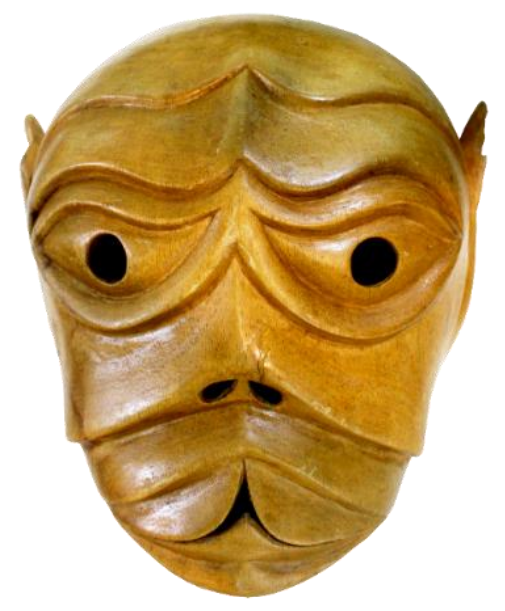

Figure 8. Moyang Gayak Mask

(Source: Researcher Documentation: 2019)

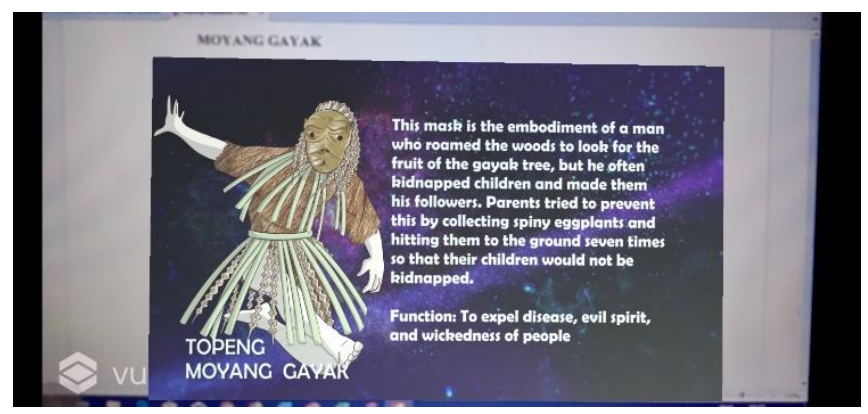

Figure 9. Visualization of Dayak Moyang Mask Infographics on Augmented Reality Views

(Source: Research Results: 2019)

The background on the screen is made in dark purple to represent Moyang Gayak's nature that is full of deception. The color purple in color theory symbolizes cruel, rough, sorrow, envy, and mystery (Wicaksono: 2013). In addition, there are some purple star effects in the background. Those things refer to Moyang Gayak who is a symbol of humans who like to mislead other humans because they want to revenge and vent their pain so that other humans feel what they feel.

\section{Moyang Tenong Jerat}

The original story of Moyang Tenong Jerat in Joanne Heng's writing in the 2000 book The Mah Meri Mask Collection published by Akademi Pengajian Melayu, Universiti Pengajian Malaya mentions: In ancient time, a human being walked into a jungle. He found traces of blood and saw an animal lying dead in front of him. The man began to follow the animal into the snare trap (Tenung Jerat). The animal was dead, being eaten and having only one half of the thigh left. Then the human was busy looking for the leaves of bantut and thorny brinjals and chop them seven times whilst chanting, "If it becomes a man, let it be one, but if a ghost, so be it."

$$
\text { Infographic visualization of }
$$

Moyang Tenong Jerat is taken from the original Moyang Tenong Jerat mask and combined with the indigenous Malaysian mask dance costumes.

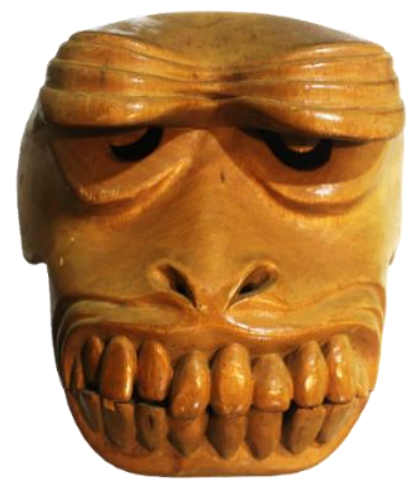

Figure 10. Moyang Tenong Jerat Mask (Source: Researcher Documentation: 2019)

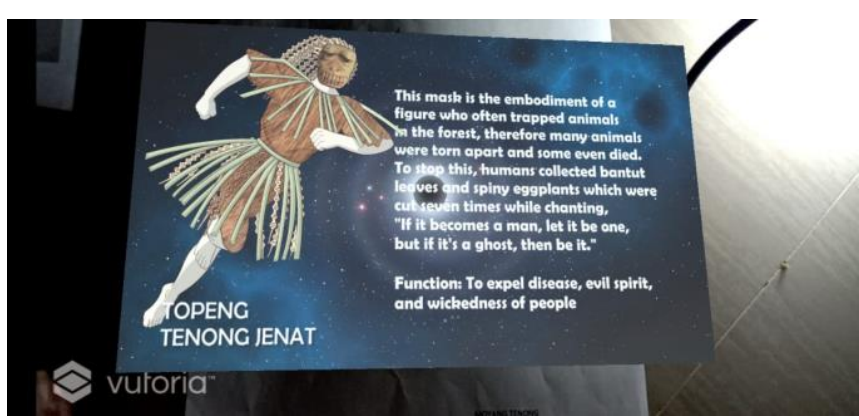


Figure 11. Visualization of Tenong Jerat's Ancestral Mask in Augmented Reality Views

(Source: Research Results: 2019)

The background on the screen is made in blue to represent Moyang Tenong Jerat's nature who is cold-blooded killer and would devour their victims without mercy. The blue color in color theory symbolizes sadness, coldness, depression (Wicaksono: 2013). In addition, there is a total lunar eclipse effect in the background that symbolizes darkness and fear. It refers to Moyang Tenong Jerat who is a symbol of humans who are greedy for whatever they desire and obtain everything they want in a bad manner.

\section{Moyang Biawak}

The original story of Moyang Biawak in Joanne Heng's writing in The Mah Meri Mask Collection in 2000 published by Akademi Pengajian Melayu, Universiti Pengajian Malaya states: Once there were seven brothers who used to catch lizards daily, but one day the youngest brother did not go. Only six brothers went into the jungle to look for lizards. However, the six brothers did not come home after the night had fallen. When the youngest brother realized that his brothers were not coming back, he thought to himself, "Why are my brothers not coming back? Is it possible that they have lost their way?"

The next morning the youngest brother went to look for his brothers in the jungle. He followed the foot-prints of the six brothers. Suddenly he found only bones scattered there. "The big and fierce lizard must have eaten my brothers. Never mind." said the youngest brother. "I will kill it." Because of his skill, he managed to kill the lizard then and there. When the spirit lizard was killed he felt rather satisfied. He took some keladi leaves and bantut leaves to make a spell so that the spirit lizard would not eat human beings again.

The youngest brother chop the leaves into pieces while chanting, "If you be a human being be a human being, if you be a lizard be a lizard, but do not eat human beings again." That was the spell of the youngest brother upon the lizard.

Infographic visualization of Moyang Biawak mask is taken from the original Moyang Tenong Jerat mask and combined with the indigenous Malaysian mask dance costumes.

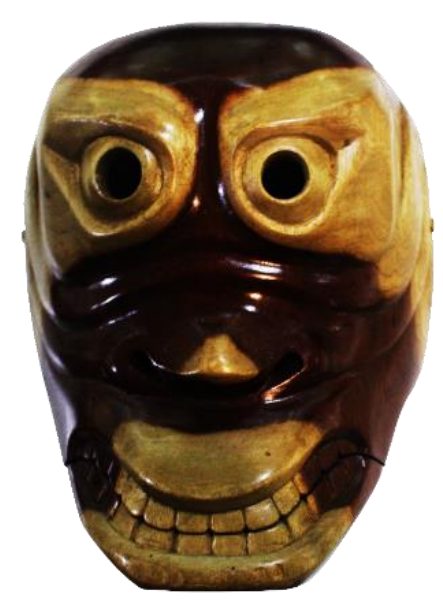

Figure 14 Moyang Biawak Mask

(Source: Researcher Documentation: 2019)

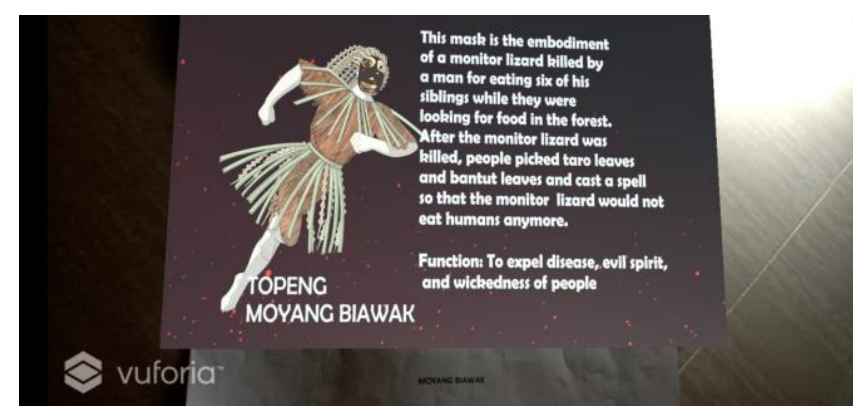

Figure 15. Visualization of Lizard Mask Infographics on Augmented Reality Views (Source: Research Results: 2019)

The background on the screen is made in dark purple to represent Moyang Biawak's nature who is cruel and likes to eat humans who enter the forest. The color purple in color theory symbolizes cruel, 
rough, sorrow, envy, and mystery (Wicaksono: 2013). In addition, there are some purple star effects in the background. This refers to the Moyang Biawak who is a symbol of greedy humans.

\section{CONCLUSION AND SUGGESTION}

\section{Conclusion}

The infographic application of Nusmari Malaysia that is Augmented Reality-based at The Museum Of Asian Art as an education media for visitors has succeeded in modernizing the delivery of information related to indigenous Malaysian tribes mask at the museum which were originally at the forms of labels. The information is transformed into attractive and interactive infographic that appeal both the young people and adults who are more and more technologically aware these days.

\section{Suggestion}

Nusmari Malaysia's application in the future will be able to be utilized by other researchers by being developed it into more interactive three-dimensional characters 


\section{References}

Arifitama, Budi. 2017. Cultural Heritage Digitalization on Traditional Sundanese Music Instrument using Augmented Reality Markerless Marker Method. Jurnal Teknologi dan Sitem Komputer. Universitas Diponegoro: Semarang.

Heng, Joanne. 2000. The Mah Meri Mask Collection. Akademi Pengajian Melayu, Universiti Pengajian Malaya: Malaysia.

https://museum.um.edu.my/. Accessed on 3 November 2019.

Ilmunesia.com. Accessed on 3 November 2019.

Kurniasih, Nuning. 2016. Infografis. Prosiding Makalah Seminar Nasional "Komunikasi, Informasi dan Perpustakaan di Era Global": Jatinangor.

Panorama Magazine.com. Accessed on 3 November 2019

Prabowo, Remo, dkk. 2015. Pengenalan Rumah Adat Indonesia berbasis Augmented Reality dengan Memanfaatkan KTP sebagai Marker. Prosiding SNATIF Ke-2.

Ratos, Datuk Anthony. 2003. Orang Asli and Their Wood Art. Times Media Private Limited: Singapore.

Salim, Andreas Jimmy. 2017. Perancangan Buku Kesenian Tentang Topeng Malangan di Kota Malang. Jurnal Desain Komunikasi Visual Adiwarna. Petra Christian University: Surabaya.

Siswanti, Sri Desy, dkk. 2016. Tracking Markerless Augmented Reality untuk Design Furniture Room.
Prosiding Annual Research Seminar Vol 2 No. 1. Sistem Komputer Fakultas Ilmu Komputer Unversitas Sriwijaya Sumatera Selatan: Indonesia.

Ulinnuha, dkk. 2018. Kajian Semiotika: Identitas Budaya Lokal dalam Film Golok Lanang Wanten Karya Darwin Mahesa. Jurnal Ikraith Ekonomika Vol 1 No 2.

Wicaksono, Arif Ranu, dkk. 2013. Komposisi Warna Website Universitas Kelas Dunia, Studi Kasus Harvard University, University of Cambridge Dan National Taiwan University. Seminar Nasional Informatika: Yogyakarta. 